\title{
Barack Obama and the South
}

\author{
Charles S. Bullock, III
}

\begin{abstract}
Despite a tradition of racism, the South contributed to Barack Obama's election as President. Obama won more electors than any Democratic nominee since 1976 although he did not carry the region. Obama's mixed performance has spawned conflicting interpretations concerning the presence of racism among the region's whites. Evidence of discrimination is at most mixed. Obama performed less well than Kerry among whites in states that have experienced less growth but elsewhere equalled or exceeded Kerry's 2004 performance. When compared with statewide Democratic candidates, Obama attracted less of the white vote than went to winners but exceeded the performance of losers. Two other possible manifestations of a racist reaction to Obama in the South also failed to materialize. Across the region there was no Bradley effect nor was there a substantial mobilization among white voters.
\end{abstract}

Observers have interpreted the meaning of Barack Obama's election for race relations in the South in vastly different ways. Some see his victory as marking the demise of the racism that characterized the South for decades. For example, Georgia Governor Sonny Perdue (2009) stressed the Obama election in a brief submitted to the Supreme Court that called for eliminating the preclearance requirement of the Voting Rights Act. Others see in the new president's inability to carry the South the persistence of racism ("Uphold the Voting Rights Act" 2009).

In determining which of these strikingly different perspectives comes closer to the truth, the standard used becomes critical. If the standard is Obama's performance in the South compared with the rest of the nation, then his loss of eight of eleven Southern states might be attributable to the persistence of racism. If, however Obama's performance is compared against that of other Democratic candidates in the region, it may support a different interpretation.

Racial considerations long dominated southern whites' voting decisions. Loewen (1982) found minimal white support for black candidates in an analysis of 40 South Carolina elections held between 1972 and 1976. He showed that more than 90 percent of the white voters typically voted against the black candidate. He concluded that among white voters, "Race is the only factor that makes a difference to them" (276). If Loewen's conclusions remain appropriate today then racism explains why white southerners rejected Obama for John McCain. A more recent analysis of racial voting patterns in congressional elections held during the 1990s found much higher

CHARLES BULLOCK is professor of political science at the University of Georgia.

The American Review of Politics, Vol. 31, Summer, 2010: 3-24

(C)2010 The American Review of Politics 
levels of white support for black candidates than Loewen's earlier research. Bullock and Dunn (1999) show that African Americans running for Congress in the South usually attract about a third of the white vote with white voters being more willing to support black candidates than black voters are to support white candidates.

Despite greater acceptance from white voters, the black congressional candidates of the 1990s failed to attract a majority of whites. The Bullock and Dunn research also shows that non-incumbent white Democrats, like black Democrats, often lost the white vote. For half a century, the Democratic Party label has been a liability in presidential elections in the South. More recently, Republicans have become favored over Democrats in congressional races (Black and Black 2004) and in legislative and local contests in several states (Lublin 2004). Reviews of partisan office holding show the dramatic increase in Republican success in the South's congressional and state legislative delegations (Lamis 1999; Rhodes 2000; Bullock et al. 2006; Bullock and Rozell 2010). Since almost all black candidates run as Democrats, some share of the white opposition to them and to Obama derives from their partisanship and not their race. Any interpretation of the Obama vote should factor in partisanship.

In assessing Obama's performance, some have compared his showing in the South with that of the non-South or the nation as a whole. Such comparisons ignore the South's more pronounced tendency to vote for Republicans. In presidential elections, the South has been more Republican than the rest of the country in every election since 1980. In Congress, the South's percentage of GOP legislators has exceeded that from the non-South since 1997 and the disparity has grown. Currently in open seat contests for the House, Republicans get five percent more of the votes in the South than the North (McKee 2010).

This article puts Obama's performance in the South in context. ${ }^{1}$ It proceeds in the following manner. We begin by examining the critical role of the South in Obama's successful campaign for the Democratic nomination. Then we turn to the general election and compare his performance with that of John Kerry in 2004. Both nominees were liberals from outside the region and since 1960 non-southern Democratic presidential candidates have struggled in the South. To the extent that race influenced southern white's voting decisions, then Obama should have gotten less of the white vote than did the Massachusetts senator. Next Obama's vote shares will be compared with that of statewide Democratic candidates. Two other possible manifestations of racial reactions to be examined are whether a Bradley Effect characterized the election and the impact of the Bema candidacy on turnout. Finally, a simple model of the Obama vote will be estimated. 


\section{Background}

On his way to amassing 365 Electoral College votes, Obama carried the bulk of the states in every region except the South and the Mountain West. Even in losing most of the South, Obama outperformed all Democratic presidential nominees since Jimmy Carter who won ten states and 118 electors in 1976. Despite the South's long history of racism, Obama achieved what eluded former Vice Presidents Walter Mondale and Al Gore, Michael Dukakis, and John Kerry none of whom won any of the region's states. Indeed, Obama ran better in the South than did two recent southern nominees, President Jimmy Carter in 1980 or Al Gore. While Obama took three states, one less than Bill Clinton secured in either of his presidential victories, Obama's 55 electors exceeded the former president's showing. ${ }^{2}$ Moreover, two of Obama's wins came in states long hostile to Democratic presidential ambitions. Virginia had last backed a Democratic presidential candidate in 1964 while North Carolina had not voted Democratic since it narrowly backed Carter in 1976 having remained Republican even when John Kerry picked its senator as his running mate.

Obama won the three states he targeted in the South. Georgia was the only other state in the region that Obama seriously contested and when the Libertarian candidate, former Georgia Representative Bob Barr, showed no appeal in the polls conducted by the Obama campaign, the Peach State got written off.

\section{Theory}

The two driving forces for change in southern politics have been the mobilization of a black electorate and the emergence of bipartisan competition. Both movements initially met resistance from white voters. In time, however, beginning with presidential elections before percolating down to lower offices (Aistrup 1996), most southern whites have come to support Republican nominees. One of the challenges in this research is to try to determine whether white opposition stemmed from Obama's race or party affiliation.

Party identification has long been the strongest correlate of voting behavior and the 2008 exit polls showed that substantial majorities of both parties' adherents cast ballots for their party's nominee. To the extent that white southerner's support for Obama parallels their support for other Democratic candidates, it bolsters the partisan explanation.

Democratic presidential candidates used to run worse among southern white voters than did Democratic congressional candidates. Prior to 1994, Democratic congressional candidates in the South attracted about half the 
white vote while the party's presidential nominees received about a third (Bullock and Rozell 2010). More recently, white support for congressional candidates has fallen to that given presidential nominees. If whites gave fewer votes to Obama than to Democratic nominees for statewide offices, that might indicate the presence of racism. However not all Democratic candidates hold equal appeal for white voters. Name recognition, constituency service, and favorable assessments of policy stands frequently induce some share of the electorate to abandon their party's nominee and support the incumbent (Mayhew 1974; Smith et al. 2009). Consequently, if Obama ran behind Democratic incumbents, that need not indicate voter racism, especially if he attracted more white votes than did Democrats who challenged Republican incumbents. Obama's white support will be compared with that of Democrats running for senator and governor.

Information theory offers an explanation for why Obama might perform worse than white Democrats running for open seats or challenging incumbents. This theory suggests that whites who know little about a black candidate often fear that should the black candidate succeed it will disadvantage whites and this fear leads them to support the white alternative (Hajnal 2007). However once whites come to know more about black candidates and how they conduct themselves in office, these fears may subside and growing numbers of whites will vote for the African American. Hajnal's (2007, 2010) extensive research into white voting in white mayoral contests with competing black and whites candidates demonstrates that the information gained as a result of a black mayor completing one term in office results in increased white support when that candidate seeks reelection. The longer a black mayor serves, the greater the impact on white attitudes. Others have shown increased white willingness to vote for African Americans seeking reelection than for black non-incumbents (Bullock 1984; Liu and Vanderleeuw 1999). Obama did not have the advantage of seeking reelection to the presidency and therefore he is expected to get fewer white votes than Democratic incumbents.

Information theory suggests that Obama, as a non-incumbent black candidate, would not secure the bulk of the white vote. Black non-incumbent mayoral candidates in the South have attracted as little as 3 percent of the vote (Memphis) and no more than 42 percent (Houston) (Hajnal 2007, 175). In congressional contests, non-incumbent southern black Democratic nominees usually received 22-34 percent of the white vote although Robert Scott (VA) did attract a bare majority (Bullock and Dunn 1999).

In recent years, non-incumbent white Democrats have struggled to attract white support in much of the South. Only one of ten white Democrats seeking open southern congressional seats in Georgia and the Carolina from 
1992-1998 got a majority of the white vote (Bullock and Dunn 1999). None of the 35 whites challenging a Republican incumbent won over most white voters.

Obama may have had less appeal for southern whites than Democratic senatorial or gubernatorial candidates even in the absence of incumbency. Candidates for state office have personal ties to a share of the electorate (Fenno 1978) and will have the opportunity to expand that circle of connections in the course of the campaign. Obama lacked long standing relationships with southern voters and while media coverage and advertising provided voters with information, few had opportunities to interact with him. Therefore Obama likely attracted fewer white votes than open seat Democratic nominees.

Yet another challenge for Democratic presidential nominees in the South is that to secure the nomination and to attract voters outside the region, they may embrace policy positions well to the left of the median, white southern voter. As Hajnal $(2007,26)$ observes, "Conservative white Republicans, by contrast, may have multiple reasons, in addition to race, for opposing liberal black candidates." For these reasons, Obama (and liberal white candidates like John Kerry) are expected to perform less well among whites than southern Democrats running statewide. Specifically, we expect Obama to attract less white support than Democratic incumbents or candidates for open seats. He may have had more appeal for whites than Democratic challengers to sitting Republicans.

Not surprisingly, Hajnal (2007) notes that white Democrats display greater tolerance for black candidacies than do white Republicans. Partisan differences lead to an expectation that Obama attracted more white Democratic than white Republican votes. A measure of Obama's acceptance to white Democrats can be gained by examining voting patterns in the presidential primaries.

Yet another race-based white reaction to the potential of black political influence is a registration backlash. At times whites desperate to maintain their political dominance have reacted to heightened black voter registration by mounting drives to register whites. The Obama campaign made concentrated efforts to register blacks in anticipation of the primary struggle with Hillary Clinton and continued enrolling African Americans until registration books for the general election closed. These efforts attracted widespread media attention. Unregistered whites who objected to Obama because of his race or were troubled by increased black registration could offset the work of his campaign by turning out to vote. We will see whether white participation rates managed to keep up with increases in black participation. 


\section{Data}

Most of the data used in this article come from exit polls. At one point we utilize results of pre-election polls compiled by Real Clear Politics. Three states report turnout data by race and for these states the official turnout figures are substituted for the estimates of turnout by race from the exit polls. Since the dependent variables in the multivariate models use interval data, OLS is used.

\section{Path to the Nomination}

Obama's win in the Iowa caucuses demonstrated his ability to attract white voters. It also unmasked the vulnerability of Hillary Clinton, long seen as the prohibitive favorite to win the Democratic nomination. The media over-interpreted the caucus victory and announced that the New Hampshire primary would be the coup de grace for Clinton. She, however, bounced back to confound the pollsters and pundits with a three percentage point victory. The next week she captured a majority of the vote in the unsanctioned Michigan primary in which Obama and most other Democratic contenders honored party rules and refused to compete.

Clinton's victories heightened the significance of South Carolina, the first southern state and the first state with a significant black population to hold a presidential primary. Emblematic of Bill Clinton's identification with African-American concerns was Toni Morrison's characterization of him as "America's first black President." Her husband's record, as well as her own, had earned Clinton endorsements from numerous black political leaders. Some black leaders, including Rep. John Lewis (D-GA), hesitated to endorse Obama calculating that America was not prepared to nominate, much less to elect a black man (Scott 2008). Would these considerations suffice to give Clinton victory in South Carolina and set her up to clinch the nomination on Super Tuesday?

Obama's 55-26 percent victory over Clinton in South Carolina ended African-American concerns about Obama's electability as he swept Palmetto State blacks 78-19 percent. The South Carolina victory set the stage for similar wins across the Deep South as well as the two Rim South states having the largest black concentrations. As shown in Table 1, Obama did especially well in Georgia (66\% of the vote), Virginia (64\%), and Mississippi (61\%). In five of the seven states won by Obama, African Americans cast at least half the votes and in Virginia Obama secured a majority of the white vote.

In southern primaries sanctioned by the Democratic Party, Obama lost only Tennessee and Clinton's adopted Arkansas - the two states where exit polls show him receiving the smallest share of the black vote. In Texas, 
Table 1. Obama's Performance in Sanctioned Southern Primaries

\begin{tabular}{ccccc}
\hline & $\begin{array}{c}\text { \% Black } \\
\text { Among Voters }\end{array}$ & Vote \% & $\begin{array}{c}\text { Obama Support } \\
\text { Black \% }\end{array}$ & White \% \\
\hline AL & 51 & 56 & 84 & 25 \\
AR & 17 & 26 & 74 & 16 \\
GA & $55^{*}$ & 66 & 88 & 43 \\
LA & $56^{*}$ & 57 & 86 & 30 \\
MS & 50 & 61 & 92 & 26 \\
NC & 34 & 56 & 91 & 37 \\
SC & $56^{*}$ & 55 & 78 & 24 \\
TN & 29 & 40 & 77 & 26 \\
TX & 19 & 47 & 84 & 44 \\
VA & 30 & 64 & 90 & 52 \\
*Official turnout figures from the appropriate secretary of state. & \\
Source: Black turnout and vote shares come from exit polls unless otherwise noted. \\
\hline
\end{tabular}

Obama narrowly lost the popular vote 51-47 percent but trumped Clinton 56-44 percent at the caucuses held on the evening of the primary. Obama's stronger caucus performance gave him a narrow victory with 99 Texas delegates to Clinton's 94.

As reported in Table 1, Obama took at least 70 percent of the black vote in each sanctioned southern primary. In his best performances, exit polls show him with just over 90 percent of the black vote and in all but three states he took over 80 percent. Only in Virginia did he also appeal to most white Democrats although he broke 40 percent in Georgia and Texas. He usually attracted about a quarter of the white vote which is in the range for black non-incumbents seeking municipal and congressional offices in the South.

Absent the impressive showing in these primaries, Obama might not have attracted the super delegates needed to clinch the nomination. As Table 2 shows, Obama won the bulk of the delegates chosen in eight of ten sanctioned contests in the South. In the non-South, Clinton won 15 of 24 sanctioned primaries. Obama claimed 55.6 percent of the primary delegates in the ten southern states, but just 51.3 percent of the delegates from other states. ${ }^{3}$ Only in the South did Obama win a majority of the region's primaries although there were other regions in which he won most of the caucuses.

\section{Obama Compared to Kerry}

Obama's stronger performance in the South than nationally during the primary season did not foretell a comparable showing in November. Instead, 
Table 2. Regional Successes of Obama and Clinton

\begin{tabular}{lcc}
\hline & Obama & Clinton \\
\hline Winners of Binding State Primaries by Region* & \\
South & 8 & 2 \\
Non-South & 9 & 15 \\
Sources of Pledged Delegates & & \\
Total & 1766.5 & 1639.5 \\
South & 422 & 337 \\
FL \& MI & 63 & 87 \\
Non-South & 1281.5 & 1215.5 \\
*The Florida primary that the Democratic Party refused to sanction is excluded. \\
\hline
\end{tabular}

the South, which played a critical role in the nomination process, gave Obama less support than other regions. Despite losing the South, Obama became the first northern Democratic nominee to win a southern state since Hubert Humphrey won Texas in 1968.

Obama managed almost 47 percent of the South's two-party vote, four points better than Kerry. As Table 3 shows, Obama outperformed Kerry in eight states with the most dramatic improvements coming in Georgia, North Carolina, Texas and Virginia where the Democratic vote share rose by 6-8 percentage points. Taking a larger share of the vote, however, need not indicate that race played a smaller role in 2008 than 2004. While Kerry received overwhelming support among blacks, with 88 percent as the median, the median for Obama exceeded that figure by eight points and he attracted 98 percent of African-American vote in four states. Obama improved on Kerry's showing among black voters in every state except Arkansas where he matched the 2004 nominee.

As impressive as Obama's showing among blacks, it is his performance among whites that will shed light on the degree of racial tolerance in the region. Overall southern whites responded to Obama as they did to Kerry with the median level of support for both being about 25 percent. Obama's victories came in the states where he performed best among white voters taking 42 percent of the white vote in Florida, 39 percent percent in Virginia and 35 percent in North Carolina. In North Carolina and Virginia Obama did better than Kerry among both blacks and whites. Obama matched Kerry's showing among Florida whites and won the Sunshine State by attracting ten percentage points more of the black vote coupled with a 13-point increase in Latino support. ${ }^{4}$ The same factors account for Obama out-performing Kerry in Texas. 


\section{Table 3. Vote Share and Racial Support for Southern Democratic Presidential Candidates in 2004 and 2008}

\begin{tabular}{lcccccc}
\hline & \multicolumn{3}{c}{ Support for Obama } & \multicolumn{3}{c}{ Support for Kerry } \\
State & Vote $\%$ & Black \% & White $\%$ & Vote \% & Black \% & White \% \\
\hline Alabama & 39 & 98 & 12 & 37 & 91 & 19 \\
Arkansas & 39 & 94 & 30 & 45 & 94 & 36 \\
Florida & 51 & 96 & 42 & 47 & 86 & 42 \\
Georgia & 47 & 98 & 23 & 41 & 88 & 23 \\
Louisiana & 42 & 94 & 14 & 42 & 90 & 24 \\
Mississippi & 43 & 98 & 11 & 40 & 90 & 14 \\
N. Carolina & 50 & 97 & 35 & 44 & 85 & 27 \\
S. Carolina & 45 & 96 & 26 & 41 & 85 & 22 \\
Tennessee & 42 & 94 & 34 & 43 & 91 & 34 \\
Texas & 44 & 98 & 26 & 38 & 83 & 25 \\
Virginia & 53 & 92 & 39 & 45 & 87 & 32 \\
Median & 44 & 96 & 26 & 42 & 88 & 25 \\
Source: Exit Polls and election returns compiled by author. & & & \\
\hline
\end{tabular}

Obama failed to match or exceed Kerry's white vote share in four states and it is these states where population growth has lagged the national rate during the last half century. Alabama, Arkansas, Louisiana and Mississippi are the only southern states to have lost congressional seats in that time. Less growth in these states may be associated with more widespread traditional attitudes among whites because of the absence of a moderating influence introduced by in-migrants. ${ }^{6}$

\section{Obama Compared to State Democrats}

Recent Democratic presidential nominees have held little appeal for southern whites. One must go back generations to find a Democratic presidential candidate able to attract the bulk of the white vote since even Carter managed just 47 percent in the course of sweeping the region except for Virginia in 1976 (Black and Black 1992). But even in years when Democratic presidential nominees won no southern state (1972, 1984, 1988, 2000, and 2004), Democrats continued to win statewide posts. Following the 2008 elections, Democrats claimed, almost a third of the South's senators, four governors and numerous statewide elected officials. Texas is the only southern state in which Democrats hold no statewide offices. Did Obama repeat the recent pattern in which the presidential nominee does less well among whites than Democrats competing for statewide offices? Results from Democrats who ran on the ticket with Obama shed light on this question. 
Every southern state except Florida had a Senate contest in 2008 and North Carolina had a gubernatorial election. Trent Lott's resignation necessitated two Senate contests in Mississippi. In the Senate contests in Table 4, the local Democrat led Obama in five contests, Obama outpaced the local Democrat in five, and in Georgia and the North Carolina gubernatorial contest, Obama and the Democrat drew equal shares of the vote. Thus Obama did not fare consistently worse than the local Democrats.

Given the advantage enjoyed by incumbents, it is not surprising that Obama trailed the Democratic senators in Arkansas and Louisiana. ${ }^{7}$ Obama also ran behind the Democrats who picked up what had been Republican Senate seats in North Carolina and Virginia. The fifth Senate candidate who outperformed Obama challenged Mississippi's appointed Republican in the special election. Obama equaled the performance of Beverly Perdue who became governor of North Carolina. Obama did better than five Democratic nominees each of whom attracted less than 45 percent of the vote. Two of these, Vivian Fingers in Alabama and Mississippi's Erik Fleming, are African Americans. Except for Perdue, Obama could not match the performance of successful local Democrats but he attracted larger shares of the vote than statewide Democrats who lost. ${ }^{8}$

Table 4 shows that as expected, Democratic candidates attracted sizable majorities of the black vote although usually unable to match Obama. In states that elected local Democrats (Louisiana, Virginia, and North Carolina) Obama and the local nominees did about as well with black voters while in other states Obama ran ahead of his party's Senate nominee with Tennessee having the greatest disparity.

We hypothesized that Obama would attract fewer white votes than Democratic incumbents or Democratic candidates for open seats but do better than Democratic challengers. As expected, he ran well behind Senators Pryor (AR) and Landrieu (LA). In winning Virginia's open seat Mark Warner took most of the white vote. Obama also got less white support than the Democrat competing in the Mississippi special election and he narrowly trailed Beverly Perdue in her successful bid to become North Carolina's governor. ${ }^{9}$ Thus, the pattern is as anticipated for Democratic incumbents and open seat candidates. Obama, however, did not consistently attract more white support than Democratic challengers. He ran ahead of the Democratic challengers to GOP senators in Alabama, Mississippi (Cochran) and Tennessee and achieved the same white support as the Democratic challenger in South Carolina. However he trailed Democratic challengers to Republican senators in Georgia, Texas and North Carolina where the electorate rejected Elizabeth Dole. The results with regard to Democratic challengers is, at best, mixed. 


\section{Table 4. Vote Share and Racial Support for Southern Democratic Statewide Candidates in 2008}

\begin{tabular}{|c|c|c|c|c|c|c|}
\hline \multirow[b]{2}{*}{ State } & \multicolumn{3}{|c|}{ upport for Statewide Democrats } & \multicolumn{3}{|c|}{ Support for Obama } \\
\hline & Vote $\%$ & Black \% & White $\%$ & Vote $\%$ & Black \% & White $\%$ \\
\hline \multicolumn{7}{|l|}{ U.S. Senate } \\
\hline Alabama (R-I) & 37 & 90 & 11 & 39 & 98 & 12 \\
\hline Arkansas (D-I)* & 79 & 91 & 78 & 39 & 94 & 30 \\
\hline Georgia (R-I) & 47 & 93 & 26 & 47 & 98 & 23 \\
\hline Louisiana (D-I) & 52 & 96 & 33 & 42 & 94 & 14 \\
\hline Mississippi Regular (R-I) & 38 & 94 & 8 & 43 & 98 & 11 \\
\hline Mississippi Special (R-I)** & $* 45$ & 92 & 18 & 43 & 98 & 11 \\
\hline N. Carolina (R-I) & 53 & 96 & 39 & 50 & 97 & 35 \\
\hline S. Carolina (R-I) & 42 & 87 & 26 & 45 & 96 & 26 \\
\hline Tennessee (R-I) & 32 & 72 & 26 & 42 & 94 & 34 \\
\hline Texas (R-I) & 43 & 89 & 27 & 44 & 98 & 26 \\
\hline Virginia (open) & 64 & 93 & 56 & 53 & 92 & 39 \\
\hline \multicolumn{7}{|l|}{ Governor } \\
\hline N. Carolina (Open) & 50 & 95 & 36 & 50 & 97 & 35 \\
\hline \multicolumn{7}{|c|}{$\begin{array}{l}\text { Source: Exit polls and election returns compiled by author. } \\
\text { *Mark Pryor faced a Green Party challenger but had no Republican opponent. } \\
\text { **Roger Wicker was an incumbent via an appointment and had not faced the electorate so he prob- } \\
\text { ably lacked the name recognition and campaign organization that frequently advantages incumbents } \\
\text { making him something of a hybrid. }\end{array}$} \\
\hline
\end{tabular}

Overall the median level of white support for Obama was 26.5 percent compared with 26 percent for the statewide Democrats. Pryor's strong showing achieved in the absence of a GOP challenger boosted the average white support for statewide Democrats to 32 percent. Eliminating the Arkansas Senate contest dropped the average white vote for statewide Democrats to 27.8 percent, slightly above the 25 percent unweighted average for Obama.

Democrats competing statewide on the ballot with Obama did slightly better with white voters than the presidential nominee. To help understand whether Obama's race accounts for the difference, we examine another comparison. How did Obama do vis-à-vis his ticket mates compared with Kerry's performance vis-à-vis statewide Democrats on the 2004 ticket? Obama did better with white voters vis-à-vis statewide Democrats on the 2008 ticket than Kerry did with other southern Democrats on the 2004 ticket. As Table 5 reports, only in Alabama and Georgia did Kerry get a larger share of the white vote than the Democratic Senate candidate and in neither case did the difference reach five points. In five Senate contests and the North Carolina gubernatorial election, the local Democrat attracted a larger 
share of the white vote than Kerry got and in four of the contests the difference exceeded five percentage points. Kerry's median white vote share (25.5\%) falls five points below the median for the statewide candidates. Recall that the median white figures for Obama and Democrats running with him were essentially equal.

While Obama appears to have done better with white voters vis-à-vis Kerry when compared to the appeal of statewide Democrats on the same ticket, this may be due to differences in the status of the 2008 and 2004 statewide Democrats. In two of the eight contests in Table 5, a Democratic incumbent sought reelection and, as anticipated ran well ahead of Kerry with whites. Kerry also got less white support than four of five Democrats seeking open Senate seats but did better with whites than the one Democratic challenger. The 2004 results better fit our expectations than did the 2008 pattern. ${ }^{10}$

The one 2004 case that fails to conform with expectations, Georgia's open Senate seat, and two of the three challengers than conform in 2008 involved African-American candidates. Taken together these suggest that black statewide candidates face longer odds than comparable white Democrats since a white presidential candidate had more appeal for white voters than a black state candidate while a black presidential candidate had more appeal than black, but usually not white, statewide challengers. None of these black candidates attracted sufficient funding to mount competitive

\section{Table 5. Vote Share and Racial Support for Southern Democratic Statewide Candidates in 2004}

\begin{tabular}{|c|c|c|c|c|c|c|}
\hline \multirow[b]{2}{*}{ State } & \multicolumn{3}{|c|}{ Support for Statewide Democrats } & \multicolumn{3}{|c|}{ Support for Kerry } \\
\hline & Vote $\%$ & Black \% & White \% & Vote $\%$ & Black \% & White $\%$ \\
\hline \multicolumn{7}{|l|}{ U.S. Senate } \\
\hline Alabama (R-I) & 32 & 80 & 15 & 37 & 91 & 19 \\
\hline Arkansas (D-I)* & 56 & 96 & 49 & 45 & 94 & 36 \\
\hline Florida (open) & 48 & 85 & 45 & 47 & 86 & 42 \\
\hline Georgia (open) & 40 & 87 & 21 & 41 & 88 & 23 \\
\hline Louisiana (open)* & 47 & 92 & 31 & 42 & 90 & 24 \\
\hline N. Carolina (open) & 47 & 87 & 30 & 44 & 85 & 27 \\
\hline S. Carolina (open) & 44 & 83 & 28 & 41 & 85 & 22 \\
\hline \multicolumn{7}{|l|}{ Governor } \\
\hline N. Carolina (D-I) & 56 & 87 & 43 & 44 & 85 & 27 \\
\hline
\end{tabular}


campaigns. Better tests of black statewide candidates' appeal to white voters may come in 2010 if Democrats nominate the African Americans running for open gubernatorial positions in Alabama and Georgia and the Florida Senate seat.

The simple model presented in Table 6 underscores the difference in successful and losing Democratic nominees in 2008. Democratic winners attract 8.7 percent more of the vote than losers. The dummy variable for whether the Democrat won may serve as a surrogate for factors such as success in raising campaign funds, name recognition and the quality of both the Democratic and the Republican candidates. ${ }^{11}$ Controlling for the outcome of the statewide Democratic contest, the share of the vote for the Democratic candidate has almost a one-to-one relationship to the vote for Obama.

While the total vote for Obama and the statewide candidate are very similar, once we control for the success of the state Democrat, did Obama lose votes among whites? To assess this possibility, Table 7 reports the result of regressing Obama's share of the white vote compared to the Democratic statewide candidate while controlling for Republican incumbency. The slope for the share of the white vote going for the Democrat (.874) indicates that when the statewide Democrat's white support grew by ten percentage

Table 6. Multivariate Analysis of the Vote for 2008 Southern Statewide Democrats

\begin{tabular}{lcc}
\hline & $\mathrm{b}$ & Std Error \\
\hline Obama support (\%) & .995 & .461 \\
Democratic win & 8.744 & 3.882 \\
Constant & -2.477 & \\
Adjusted $\mathrm{R}^{2}$ & .72 & \\
$\mathrm{~N}$ & 12 & \\
\hline
\end{tabular}

Table 7. Multivariate Analysis of Obama's Share of the White Vote

\begin{tabular}{lcc}
\hline & $\mathrm{b}$ & Std Error \\
\hline White support for state Democrat & .874 & .201 \\
Republican Incumbency & 9.316 & 5.766 \\
Constant & -7.098 & \\
Adjusted $\mathrm{R}^{2}$ & .67 & \\
$\mathrm{~N}$ & 12 & \\
\hline
\end{tabular}


points, Obama experienced an 8.7 point increase. Thus Obama ran less well among whites than did the local Democrats after controlling for Republican incumbency. However, the slope associated with Republican incumbency indicates that Obama got 9.3 percentage points more of the white vote than a local Democrat who challenged a sitting Republican, in line with our expectations.

\section{Bradley Effect}

Did white opposition to Obama lead to a Bradley or Wilder Effect? Named for two black gubernatorial candidates from the 1980s, this phenomenon is manifest when a black candidate's vote share fails to match preelection polls because some white voters tell pollsters they plan to support the black candidate but then cast their ballot for the white opponent. ${ }^{12}$ Table 8 presents the average support for Obama from the Real Clear Politics web site for the polls conducted just before Election Day. Only in Arkansas did Obama's share of the vote not exceed projections from the average of the final polls although in most states his share of the vote falls within the margin of error of most of the polls used to calculate the Real Clear Politics average. Except for Arkansas, no evidence exists of a Bradley Effect; instead, the polls failed to capture the full extent of the support for the AfricanAmerican candidate. Even in the states with the greatest racial polarization, Alabama and Mississippi, Obama's vote exceeded his poll numbers.

Table 8. Support for Obama in the Final Polls and Actual Vote Share (all figures are percentages)

\begin{tabular}{lcc}
\hline & $\begin{array}{c}\text { Real Clear Politics } \\
\text { Final Average }\end{array}$ & Vote Share \\
\hline Alabama & 33.5 & 38.8 \\
Arkansas & 43.0 & 38.8 \\
Florida & 49.0 & 50.9 \\
Georgia & 45.8 & 47.0 \\
Louisiana & insufficient polling & 42.1 \\
Mississippi & 39.3 & 42.7 \\
North Carolina & 48.0 & 49.9 \\
South Carolina & 43.0 & 44.9 \\
Tennessee & 38.8 & 41.8 \\
Texas & 40.5 & 43.8 \\
Virginia & 50.2 & 52.7 \\
Source: Real Clear Politics. & & \\
\hline
\end{tabular}




\section{Changing Make-up of the Electorate}

Realizing that strong black turnout would likely be critical to success, the Obama campaign promoted black registration. To the extent that it succeeded, this helps account for his relatively strong performance in the South. While Obama generally ran better than Kerry in the South as reported in Table 3, Table 9 shows that in most states the share of the vote cast by blacks in 2008 is not substantially higher than in 2004. The largest gains in black participation occurred in Georgia (5 percentage points), South Carolina (4 points), Alabama (4 points), and Louisiana (3 points) while black participation fell by three points in Arkansas and North Carolina. In other states the black percentage in 2008 was within one point of 2004. While the share of the votes cast by African Americans did not increase appreciably in most states, the share coming from whites declined by at least three percentage points in seven states with the largest decreases coming in Alabama ( 8 points) and Georgia (7 points). In contrast with what often occurs in municipal elections that elect the first black mayor (Hajnal 2007; Preston 1983), the Obama candidacy did not stimulate a massive countermobilization among whites.

Table 9. Proportion Black and White in the 2004 and 2008 Electorate

\begin{tabular}{lcccc}
\hline & \multicolumn{2}{c}{2008 Turnout Share } & \multicolumn{2}{c}{ 2004 Turnout Share } \\
State & Black \% & White \% & Black \% & White \% \\
\hline Alabama & 29 & 65 & 25 & 73 \\
Arkansas & 12 & 83 & 15 & 83 \\
Florida & 13 & 71 & 12 & 70 \\
Georgia & $30^{*}$ & $64 *$ & $25^{*}$ & $71 *$ \\
Louisiana & $30^{*}$ & $67^{*}$ & $27 *$ & $70^{*}$ \\
Mississippi & 33 & 62 & 34 & 65 \\
N. Carolina & 23 & 72 & 26 & 71 \\
S. Carolina & $31 *$ & $69 *$ & $27 *$ & $72 *$ \\
Tennessee & 12 & 81 & 13 & 84 \\
Texas & 13 & 63 & 12 & 66 \\
Virginia & 20 & 70 & 21 & 72 \\
*Figures from official state turnout computations. & & \\
Source: Compiled by author from exit polls, except as noted. \\
\hline
\end{tabular}




\section{White Evangelicals}

Obama ran as well among African Americans in the South as in the rest of the nation but had substantially less appeal to southern whites than nationwide. The exit polls show Obama receiving 43 percent of the white vote across the nation. In the South, he comes up just short of 30 percent of the white vote.

The core constituency for the Republican Party in much of the South consists of white evangelicals. ${ }^{13}$ In Arkansas and Tennessee evangelicals cast the bulk of the votes in 2008. In much of the rest of the South, they constituted more than 40 percent of the vote composing the smallest portion of the electorate in Florida (24\%) and Virginia (28\%), the two states where Obama ran best. Across the South evangelicals cast 37 percent of the vote compared with 26 percent nationwide. Nationwide 74 percent of the evangelicals backed McCain which matched his poorest showing in any southern state. His strongest performances among the born again came in Mississippi (94\%), Louisiana (93\%), and Alabama (92\%). He took at least 85 percent of the evangelical vote in each of the five Deep South states. The higher incidence of evangelicals in the South and their greater support for McCain suggests yet another non-racial explanation for the difference in Obama's performance in the South compared with the rest of the nation.

\section{Multivariate Analysis}

With only eleven states, it is impossible to include all variables of interest in a single model simultaneously. In preparing this section alternative models have been estimated and only the most successful will be presented.

A share of Obama's vote came from individuals who consistently support the Democratic Party. As expected, when the Obama vote share is regressed on the Kerry vote share, the relationship is strong and positive.

In addition to support for Kerry, which sets a baseline of Democratic voting, we anticipate that Obama's greater appeal among blacks helped him improve on Kerry showing. A substantial literature and an assumption in most voting rights cases is that African Americans prefer to be represented by one of their own and strongly support black candidates (Davidson and Grofman 1994; Bullock and Dunn 1999; Wright 2000; Liu and Vanderleeuw 2006). Therefore Obama's overall vote share should correlate positively with the increase from 2004 to 2008 in the proportion of the AfricanAmerican vote cast for the Democratic presidential nominee.

As noted above, the GOP's core constituency in the South is white religious conservatives or evangelicals (Kellstedt et al. 2007; Bullock and 
Smith 2005). In states where white evangelicals cast a larger share of the vote, Obama probably did less well.

When Obama's vote share is regressed on the vote for Kerry, the increase in black support for the Democratic nominee from 2004-2008 and the size of the white evangelical vote, the model in Table 10 explains 70 percent of the variance. The Kerry vote correlates strongly with Obama's vote, but he added to that with greater support among blacks. Obama did less well in states with high percentages of white evangelicals. Collinearity checks show that not to be a problem.

Table 10. Multivariate Model of Support for Obama in the South

\begin{tabular}{lcc}
\hline & Coefficient & Std Error \\
\hline Kerry's \% of the Vote & .986 & .305 \\
Change in Black Support from 2004 & .395 & .193 \\
\% White Evangelical & -.156 & .098 \\
Constant & 6.290 & \\
Adjusted R & .70 & \\
$\mathrm{~N}$ & 11 & \\
\hline
\end{tabular}

\section{Conclusion}

The South contributed significantly in Barack Obama's nomination providing stronger support than he received from primary voters in other parts of the country. On his way to becoming President, Barack Obama won more southern Electoral College votes than any Democrat since Jimmy Carter in 1976. In light of the South's historic racial intolerance and the weak performance of recent Democratic nominees for President and many candidates for statewide posts, winning more than a third of the region's Electoral College vote constituted the strongest showing by a non-southern Democratic presidential nominee since John Kennedy.

While whites and blacks responded very differently to the Obama campaign, a sizable racial divide also characterized Kerry's candidacy and most 2004 and 2008 statewide contests for which exit poll data exist as only two Democratic Senate candidates won the bulk of the white vote and one of these had only a third party opponent. Neither John Kerry nor any 2004 southern Democratic senatorial or gubernatorial candidates got majority support among whites. Although the most successful statewide Democrats drew more white support than Obama, he held at least as much appeal for 
white voters as did losing statewide Democrats. Obama failed to get the bulk of the white vote but that is common for statewide Democratic candidates in the South. Most Democrats running statewide in the South lose as did Obama in eight states. Obama got fewer white votes than Democratic incumbents and open seat candidates, as expected. That he did not consistently do better among whites than Democratic challengers may be the result of lingering racism. Obama's share of the white vote is in line with the performance among white voters of non-incumbent black mayoral candidates in the southern cities (Hajnal 2007) and of black candidates running for open congressional seats (Bullock and Dunn 1999). Despite little effort in most of the South, Obama does about as well with whites as African-American candidates seeking open seats even though those candidates had in-state ties and campaigned more intensively among southern white voters. Obama's failure to carry eight states reflects not so much rejection because of his race but rather the preference of the region's voters for Republicans. This preference for Republicans is especially strong among evangelical whites.

Two other aspects of the election that might have provided evidence of a racist response failed to do so. Unlike in the past when polls overestimated support for black candidates because some white voters deceived pollsters, Obama ran ahead of his poll numbers in all but one state. Nor do the figures on the racial makeup of the electorate indicate a strong white counter mobilization in the face of Obama's nomination.

Race of the voter persists as a major cleavage in southern politics and the prospects for Democratic presidential nominees succeeding remain especially poor across the Deep South. Where he fared worst, he could not attract even one in six white voters so that the difference in preferences of black and white voters reached at least 80 percentage points! In the three states Obama carried he increased his share among black voters and one other major ethnic group. In two of the states where Obama had the least appeal for whites, Alabama and Mississippi, Democratic candidates for the Senate also failed to attract as much as a fifth of the white vote. In Louisiana, the white incumbent did substantially better among white voters than Obama but even with the advantages of incumbency and being the daughter of a former New Orleans mayor, Mary Landrieu secured only a third of the white vote.

The strongest evidence that his race cost Obama votes comes from the comparison with Democrats challenging Republican senators in 2008. Theory predicted that Obama would attract more support than Democratic challengers but that did not consistently occur. But even for these voters, the portrayal of Obama as a liberal, coming from a northern state, the lack of an Obama campaign in the state-these and other factors might explain his inability do better than many other Democratic candidates in attracting white 
voters. While the South still has some whites who will reject a candidate solely on the basis of race, partisanship and incumbency go further than race of the candidate in explaining why Obama did less well in the South than in most of the nation.

\section{NOTES}

${ }^{1}$ The South is defined as the eleven states that seceded.

${ }^{2}$ Clinton got 39 southern Electoral College votes in 1992 and 51 in 1996. Obama also got a larger share of his electors from the South (15\%) than Clinton did in 1992 $(10.5 \%)$ or $1996(13.5 \%)$.

${ }^{3}$ Including delegates awarded from Michigan, Obama's share outside ten southern states drops to $50.8 \%$.

${ }^{4}$ Exit polls show Obama with $57 \%$ of the Latino vote compared with $44 \%$ for Kerry.

${ }^{5}$ Obama got $63 \%$ of the Texas Latino vote up from Kerry's $50 \%$. The one point Obama increase among Anglo voters is not statistically significant.

${ }^{6} \mathrm{Hood}$ and McKee (forthcoming) demonstrate the critical role of recent in-migrants to North Carolina in that state's vote for Obama. The North Carolina finding fits with the proposition that whites in states experiencing slower growth would be less likely to support Obama.

${ }^{7}$ Arkansan Mark Pryor was so popular that no Republican came forward to challenge him and he easily disposed of his third party opponent.

${ }^{8}$ Four states elected other statewide officials in addition to those included in exit polls. Alabama elected six statewide officials, a senator and six judges. Obama ran ahead of the Senate candidate as shown in Table 2 but behind the Democratic judicial nominees. Obama received more votes than the Democratic nominees for senator and the public service commissioner in Georgia and his $47 \%$ of the vote was in the middle of the range for the three (46.8-47.2\%). North Carolina elected nine constitutional officers. Obama received more votes than four of Democrats competing for these posts and a larger percentage of the vote than two. The median number of votes for the eleven Democrats (nine constitutional officers plus president and senator) on the statewide ballot was $2,146,189$ just above Obama's 2,142,651. The median vote percentage for the Democratic nominees was $51.6 \%$. The Texas ballot had Democrats competing for eight statewide posts. The range in their share of the vote was $42.8-45.9 \%$; Obama received $43.7 \%$. In the four states, Obama's performance was in line with that of local Democrats except in Alabama where he ran well behind Democratic judicial candidates.

${ }^{9}$ While the second Mississippi Senate seat was not technically an open seat since Roger Wicker had been appointed upon Trent Lott's resignation, Wicker had not won the seat in an election and therefore this contest had some of the trappings of an open seat competition.

${ }^{10}$ The same pattern exists for 2000 with $\mathrm{Al}$ Gore attracting fewer white votes than Democratic incumbent and open seat candidates and more than Democratic challengers. As in 2004, none of these Democrats attracted a majority of the white vote.

${ }^{11}$ With so few cases it is impossible to include a full range of possible independent variables and controls. 
${ }^{12}$ Tom Bradley, mayor of Los Angeles, competed as the Democratic nominee for governor in California in 1982 and 1986. In the first contest, pre-election polling predicted a Bradley victory but following the counting of absentee votes, he lost by almost 100,000 votes. Douglas Wilder became the nation's first elected black governor when he won that office in Virginia in 1989. Pre-election polling had shown Wilder with a comfortable lead and even the exit polls predicted a ten-point victory (Edds 1990). While Wilder did win, it proved a nail biter with a margin of less than 7,000 votes out of almost 1.8 million cast. The Bradley or Wilder Effect thus refers to a situation in which a black candidate fails to perform at the level anticipated based on polling.

${ }^{13}$ An extensive literature has developed dealing with the role of religious conservatives in the South. The collections edited by Rozell and Wilcox $(1995,1997)$, Green and associates (2000) and Cleary and Hertzke (2006) include a number of case studies of individual southern states. A review of the role of Christian conservatives in southern elections appears in Green and colleagues (2010). Contributors explore multiple facets of the influence of the religion in the South in Feldman (2005). Miller (2009) describes the role of the leading evangelist of the latter half of the 20th century in promoting the Republican Party in the South.

\section{REFERENCES}

Aistrup, Joseph A. 1996. The Southern Strategy Revisited: Republican Top-Down Advancement in the South. Lexington: University Press of Kentucky.

Black, Earl, and Merle Black. 1992. The Vital South. Cambridge, MA: Harvard University Press.

Black, Earl, and Merle Black. 2004. The Rise of Southern Republicans. Cambridge, MA: Belknap Press.

Bullock, Charles S., III. 1984. Racial Crossover Voting and the Election of Black Officials. Journal of Politics 46(February):238-251.

Bullock, Charles S., III, and Richard E. Dunn. 1999. The Demise of Racial Districting and the Future of Black Representation. Emory Law Journal 48(Fall):1209-1253.

Bullock, Charles S., III, Donna Hoffman, and Ronald Keith Gaddie. 2006. Regional Variations in the Realignment of American Politics, 1944-2004. Social Science Quarterly 87(September):494-518.

Bullock, Charles S., III, and Mark J. Rozell. 2010. Introduction: Southern Politics in the Twenty-First Century. Pp. 1-24 in The New Politics of the Old South, 4th ed., eds. Charles S. Bullock, III, and Mark J. Rozell. Lanham, MD: Rowman and Littlefield.

Bullock, Charles S., III, and Mark C. Smith. 2005. The Religious Right and Electoral Politics in the South. In Politics and Religion in the White South, ed. Glenn Feldman. Lexington: University of Kentucky Press.

Cleary, Edward L., and Alan D. Hertzke, eds. 2006. Representing God at the Statehouse. Lanham, MD: Rowman and Littlefield.

Davidson, Chandler, and Bernard Grofman, eds. 1994. Quiet Revolution in the South. Princeton, NJ: Princeton University Press.

Edds, Margaret. 1990. Claiming the Dream: The Victorious Campaign of Douglas Wilder of Virginia. Chapel Hill, NC: Algonquin Books.

Feldman, Glenn, ed. 2005. Politics and Religion in the White South. Lexington: University Press of Kentucky. 
Fenno, Richard F., Jr. 1978. Home Style: House Members in their Districts. Boston: Little, Brown.

Green, John C., Mark J. Rozell, and Clyde Wilcox, eds. 2000. Prayers in the Precincts: The Christian Right in the 1998 Elections. Washington, DC: Georgetown University Press.

Green, John C., Lyman A. Kellstedt, Corwin E. Smidt, and James L. Guth. 2010. The Soul of the South: Religion and Southern Politics in the New Millennium. In The New Politics of the Old South, eds. Charles S. Bullock, III, and Mark J. Rozell. Lanham, MD: Rowman and Littlefield.

Hajnal, Zoltan L. 2001. White Residents, Black Incumbents, and a Declining Racial Divide. American Political Science Review 95(September):603-617.

Hajnal, Zoltan L. 2007. Changing White Attitudes toward Black Political Leadership. New York: Cambridge University Press.

Hajnal, Zoltan L. 2010. Americas Uneven Democracy: Race, Turnout and Representation in City Politics. New York: Cambridge University Press.

Hood, M.V., III, and Seth McKee. Forthcoming. What Made Carolina Blue? In-Migration in the 2008 North Carolina Presidential Vote. American Politics Review.

Kellstedt, Lyman A., James L. Guth, John C. Green, and Corwin E. Smidt. 2007. The Soul of the South: Religion and Southern Politics in the Twenty First Century. In The New Politics of the Old South, 3rd ed., eds. Charles S. Bullock, III, and Mark J. Rozell. Lanham, MD: Rowman and Littlefield.

Lamis, Alexander P., ed. 1999. Southern Politics in the 1990s. Baton Rouge: Louisiana State University Press.

Liu, Baodong, and James M. Vanderleeuw. 1999. White-Voter Response to Black Political Power: The Case of New Orleans, 1984-1994. Southeastern Political Review 27(March):175-188.

Liu, Baodong, and James M. Vanderleeuw. 2007. Race Rules: Electoral Politics in New Orleans, 1965-2006. Lanham, MD: Lexington Books.

Loewen, James W. 1982. Statement presented before the Subcommittee on Civil and Constitutional Rights of the House Judiciary Committee. Hearings on the extension of the Voting Rights Act, 97th Congress, first session.

Lublin, David. 2004. The Republican South: Democratization and Partisan Change. Princeton, NJ: Princeton University Press.

Mayhew, David R. 1974. Congress: The Electoral Connection. New Haven, CT: Yale University Press.

McCrary, Peyton. 1990. Racially Polarized Voting in the South: Quantitative Evidence from the Courtroom. Social Science History 14(Winter):507-531.

McKee, Seth C. 2010. Republican Ascendancy in Southern House Elections. Boulder, CO: Westview Press.

Miller, Steven P. 2009. Billy Graham and the Rise of the Republican South. Philadelphia: University of Pennsylvania Press.

Perdue, Sonny. 2009. Brief filed with the U.S. Supreme Court in Northwest Austin Municipal Utility District Number 1 v. Holder.

Preston, Michael B. 1983. The Election of Harold Washington: Black Voting Patterns in the 1983 Chicago Mayoral Race. PS(Summer):486-488.

Rhodes, Terrel. 2000. Republicans in the South. Westport, CT: Praeger.

Rozell, Mark J., and Clyde Wilcox, eds. 1995. God at the Grass Roots: The Christian Right in the 1994 Elections. Lanham, MD: Rowman and Littlefield.

Rozell, Mark J., and Clyde Wilcox, eds. 1997. God at the Grass Roots, 1996: The Christian Right in the 1996 Elections. Lanham, MD: Rowman and Littlefield. 
Scott, Alexis. 2008. Personal interview conducted by the author, December 11.

Smith, Steven S., Jason M. Roberts, and Ryan J. Vander Wielen. 2009. The American Congress, 6th ed. New York: Cambridge University Press.

Uphold the Voting Rights Act. 2009. New York Times, January 25.

Wright, Sharon D. 2000. Race, Power and Political Emergence in Memphis. New York: Garland Publishing. 